\title{
Yeast Immobilization on Peanut Hulls for Potential Application in Beer Fermentation
}

\author{
${ }^{1}$ Waldir D. Estela-Escalante, ${ }^{2}$ Sergio Rosales-Mendoza and ${ }^{2}$ Mario Moscosa-Santillán \\ ${ }^{1}$ Universidad Nacional Mayor de San Marcos. Facultad de Química e Ingeniería Química. Av. Germán Amezaga 375 Ciudad \\ Universitaria, Pabellón B, Lima 01, Perú. \\ ${ }^{2}$ Universidad Autónoma de San Luís Potosí. Facultad de Ciencias Químicas. Av. Dr Manuel Nava 6,Zona Universitaria, San \\ Luis Potosí, SLP, CP. 78210, México.
}

Article history

Received: 25-03-2019

Revised: 10-06-2019

Accepted: 19-07-2019

Corresponding Author: Waldir Desiderio Estela Escalante. Universidad Nacional Mayor de San Marcos. Facultad de Química e Ingeniería Química. Av. Germán Amezaga 375, Ciudad Universitaria, Lima 01, Perú

Email: waldir.estela@unmsm.edu.pe

\begin{abstract}
The potential of using peanut hulls as support material for immobilization of yeast cells during beer fermentation was evaluated. After treatment of peanut hulls with $0.5 \%(\mathrm{w} / \mathrm{v}) \mathrm{NaOH}$, FTIR analysis revealed an important change on its chemical composition. For instance, the proportion of lignin decreased and as a result the adsorption of yeast cells onto the support material during fermentation was favoured. Cell adhesion onto the conditioned support in $8^{\circ}$ Brix laboratory malt wort as fermentation medium was evaluated, observing a maximal cell adhesion $\left(2.56 \times 10^{8}\right.$ cells/g of dried support $)$ at $20.5 \mathrm{~h}$ of cultivation. Evaluations of the performance of the biocatalyst in fermentations at $15 \pm 0.5^{\circ} \mathrm{C}$ in $14^{\circ}$ Brix laboratory malt wort indicated a proper stability in terms of physical integrity (confirmed by SEM observation) and improved fermentation kinetics. The fermentation time was shortened to approximately four days and the rates of reducing sugar consumption and ethanol production were improved when compared to fermentations carried out with free suspended cells. These results show a promising potential of peanut hulls as support material in beer fermentation.
\end{abstract}

Keywords: Yeast Immobilization, Peanut Hulls, Natural Supports, Beer Fermentation

\section{Introduction}

Immobilization technology of cells has been used over the last years in several bioprocesses including alcoholic fermentation. There are several immobilization methods listed in the literature, which are classified based on the way in which the cells interact among them and with the support material. Immobilization methods include natural or artificial flocculation, entrapment within a porous matrix, immobilization on the surface of a solid structure and mechanical containment behind a barrier (Kourkoutas et al., 2004). From the volumetric production point of view, beer production is the most important alcoholic fermentation process worldwide; which is commonly carried out with freely suspended yeast cells dispersed in the fermenters. In the last decades, the immobilization of yeast has been investigated for beer fermentation to improve the sensory quality of the product and decrease the cost of the process (Virkajarvi and Pohjala, 2000; Willaert and Nedovic, 2006). It has been showed that immobilization of yeast improves the fermentation kinetics: the fermentation time is diminished in comparison to fermentations with free cells, the ethanol productivity increases and the fermentation profile at low temperature is improved (Kopsahelis et al., 2007). Explored approaches in this field include the immobilization by entrapment in polymeric matrixes and adsorption on solid materials. Immobilization by entrapment in polymeric matrix comprised the use of commercial polymers such as alginate, chitosan, carrageenan and PVA (Raymond et al., 2004; Bezbradica et al., 2007; Almonacid et al., 2012). However, these materials are costly and in some cases are not easily available. The search for cheaper support materials derived from agricultural residues is considered a viable alternative to overcome such limitations. These organic materials should be cheap, abundant in nature, nontoxic and show good biocatalytic stability. There are few reports regarding the use of natural supports for yeast immobilization in beer fermentation, including the use of lignocellulosic materials such as shavings and brewer's spent grains (Branyik et al., 2004; 2006; Kopsahelis et al., 2007; Dragone et al., 2007; 2008), gluten pellets (Bardi et 
al., 1997), dried figs (Bekatorou et al., 2002) and corn cobs (Branyik et al., 2006). The following mechanisms of yeast immobilization have been proposed to explain how the movement of cells is limited upon interaction with the support: cell-support adhesion, cell-cell attachment and cell adsorption (accumulation) inside natural shelters (support's surface roughness) (Branyik et al., 2004).

Furthermore, agroindustrial residues are promising materials that could be used for immobilization of cells. In this sense, peanut hulls are typically generated in large quantities in the food industry worldwide. Peanut has an agroindustrial importance because of its wide use, for instance in the production of peanut butter and oil. Additionally, peanuts are consumed directly in different forms (dried, toasted, salted, spiced, etc.). Peanut is cultivated in most countries on the world. The largest producers are USA and China. Statistical data showed the production of 3.28 and 17.00 million metric tons (2017) by these two countries, respectively (STATISTA, 2017). The hulls constitute $33 \%$ of the weight of peanuts. Thus, large amounts of peanut hulls are available throughout the world. Only a small percentage of hulls are being used in applications such as feedstock and adsorbent material, while the majority is discarded as waste. Composition of peanut hulls comprises moisture $8-10 \%$, protein $6-7 \%$, fat $1 \%$, fiber $60-70 \%$, cellulose $34-45 \%$, lignin $27-33 \%$, ash $2-4 \%$ (Brown et al., 2000; Tanyildizi, 2011). Cellulose and lignin are polymers rich in carboxyl and hydroxyl functional groups, which may potentially bind cells in an aqueous solution. Although a wide variety of agroindustrial residues are generated worldwide and could serve as supports for immobilization of yeast, only few of them have been applied in fermentation processes at the industrial scale.

The present study was focused on exploring for the first time the potential of peanut hulls as a cheap and environment-friendly support material for yeast immobilization during beer fermentation.

\section{Materials and Methods}

\section{Yeast Strain and Maintenance}

The commercial lager beer yeast Saccharomyces cerevisiae S-23 was used in the study. The yeast was maintained at $7^{\circ} \mathrm{C}$ on malt extract agar slants and subcultured every three months.

\section{Support Material Preparation and Conditioning}

Peanut hulls discarded as residues after the consumption was used to prepare the support material. Peanut hulls were manually cleaned to separate soil residues and subsequently mechanically ground in small pieces using a grinder. The material was sieved through a 10-mesh sieve (2.0 mm opening) and those retained in a12 mesh sieve (1.70 mm opening) were selected to be delignified. Delignification process was carried out by immersion of the ground peanut hulls in $0.5 \%(\mathrm{w} / \mathrm{v})$ $\mathrm{NaOH}$. Erlenmeyer flasks containing $20.0 \mathrm{~g}$ ground peanut hulls and $200 \mathrm{~mL} \mathrm{NaOH}$ solution were shaken at $120 \mathrm{~min}^{-1}, 30^{\circ} \mathrm{C}$ for $24 \mathrm{~h}$. The delignified support material was subsequently rinsed with distilled water until neutral $\mathrm{pH}$. Subsequently, the delignified support material was dried at $70^{\circ} \mathrm{C}$ till constant weight and the supports were kept in a hermetic plastic bag until their use.

\section{FTIR Analysis}

A FTIR spectrophotometer (Shimatzu, IR Affinity-1, Japan) was used to identify the chemical functional groups present in the support material. IR absorbance data were obtained for wavenumbers in the range of $700-4000 \mathrm{~cm}^{-1}$ and analyzed using IRSolution ${ }^{\circledR}$ software provided by the FTIR spectrophotometer manufacturer. The support material was milled and approximately $0.5 \mathrm{~g}$ of biomass was used for the analysis.

\section{Yeast Propagation}

Propagation of yeast was carried out in $0.5 \mathrm{~L}$ Erlenmeyer flasks containing $0.2 \mathrm{~L}$ of $8^{\circ} \mathrm{C}$ Brix laboratory malt wort. Propagation was carried out at $28^{\circ} \mathrm{C}, 200 \mathrm{~min}^{-1}$ for $48 \mathrm{~h}$. The laboratory malt wort was prepared from a concentrated malt extract (Pilsner, Briess-CBW®). The wort malt was pasteurized at $115^{\circ} \mathrm{C}$ for $15 \mathrm{~min}$ after dilution with distilled water. After propagation, cells were collected by centrifugation (6000 $\mathrm{min}^{-1}$ for $\left.8 \mathrm{~min}\right)$ and resuspended in the same fermentation medium before inoculation. Unless otherwise stated, each fermentation flask was inoculated with $5 \%(\mathrm{v} / \mathrm{v})$ of inoculum.

\section{Attachment of Viable Yeast Cells on Support Materials}

Experiments of attachment of viable yeast cells on supports were carried out in $0.25 \mathrm{~L}$ Erlenmeyer flasks containing $0.1 \mathrm{~L}$ of $12^{\circ} \mathrm{C}$ Brix laboratory malt wort prepared as previously stated. To determine the amount of viable cells attached onto the supports at different time points, eight cultures in Erlenmeyer flasks containing the same volume of medium and cell concentration were established. Erlenmeyer flasks were inoculated with 5\% $(\mathrm{v} / \mathrm{v})$ of inoculum and after gently mixing; approximately $1.0 \mathrm{~g}$ of dried support was added to each flask. The cultivation conditions were $25^{\circ} \mathrm{C}$ and $120 \mathrm{~min}^{-1}$. Every three or four hours one Erlenmeyer flask was used to determine the amount of attached viable cells at the corresponding time point.

Evaluation of the viable attached cells was conducted by carefully separating the supports from the fermentation medium. The supports were gently rinsed with sterile distilled water in order to eliminate the weakly attached cells. The supports were subsequently placed in $0.25 \mathrm{~L}$ Erlenmeyer flasks containing $40 \mathrm{~mL}$ of Ringer solution (1/4 strength) and agitated at $120 \mathrm{~min}^{-1}$ for $1 \mathrm{~h}$ in an 
orbital shaker and subsequently agitated vigorously at 300 $\min ^{-1}$ for five minutes. The supernatant was used to determine the concentration of viable cells by the method of methylene blue staining using a Neubauer chamber.

\section{Fermentations with Immobilized Yeast Cells}

Fermentation experiments with yeasts immobilized on the supports were carried out in $0.5 \mathrm{~L}$ Erlenmeyer flasks containing $350 \mathrm{~mL}$ of pasteurized $14^{\circ}$ Brix laboratory malt wort prepared from a concentrated malt extract (Pilsner, Briess-CBW®). Approximately 2.0 grams of support containing approximately $2.56 \times 10^{8}$ viable cells/g of dried support were aseptically inoculated into Erlenmeyer flasks. Fermentation trials were performed under static conditions at $15 \pm 0.5^{\circ} \mathrm{C}$. A control experiment was implemented with suspended cells under the same conditions to evaluate the effect of immobilization in the fermentation kinetics. Erlenmeyer flasks were stoppered with an air locker device in order to avoid contamination. Samples were taken every $24 \mathrm{~h}$ under aseptic conditions in a laminar flow cabinet and freezed till their analyses. Experiments were carried out by triplicate.

Immobilization of cells onto the support was conducted as follows: cells propagated in $8^{\circ}$ Brix laboratory malt wort at $28^{\circ} \mathrm{C}, 200 \mathrm{~min}^{-1}$ for $48 \mathrm{~h}$ were collected by centrifugation and re-suspended in $0.5 \mathrm{~L}$ Erlenmeyer flasks containing 0.2 $\mathrm{L}$ of pasteurized $12^{\circ}$ Brix laboratory malt wort and incubated along with 2.0 grams of dried support at $28^{\circ} \mathrm{C}$ at $120 \mathrm{~min}^{-1}$. After $20.5 \mathrm{~h}$ of incubation (time of maximal cell attachment), the supports with attached cell were carefully collected under aseptic conditions and rinsed twice with sterile distilled water and subsequently used as biocatalyst (yeast cells immobilized on the support material).

\section{Scanning Electron Microscopy (SEM)}

Pieces of the biocatalyst were gently rinsed with sterile distilled water over a sterile filter paper and dried at $30^{\circ} \mathrm{C}$ in a desiccator. The support containing immobilized yeast cells was coated with a thin gold layer by vacuum evaporation and subjected to SEM analysis.

\section{Chemical Analysis}

Ethanol levels were determined by liquid chromatography (HPLC), reducing sugars by the DNS method (Miller, 1959), Free Amino Nitrogen (FAN) by the method of ninydrine (Lie, 1973), viable cells by the method of methylene blue staining (ASBC, 1992) and pH potentiometrically. Ethanol quantification was performed in a HPLC Agilent 1260 infinity, provided with autosampler, RID detector and column type $\mathrm{HC} 75, \mathrm{Ca}^{+2}$ form $(305 \times 7.8 \mathrm{~mm})$. The samples were centrifuged $(8000$ $\mathrm{min}^{-1}$ for $10 \mathrm{~min}$ ), filtered and diluted with $\mathrm{H}_{2} \mathrm{SO}_{4} 10 \mathrm{mM}$ before injection. The working conditions were: $28^{\circ} \mathrm{C}$ column temperature and $5 \mathrm{mM} \mathrm{H}_{2} \mathrm{SO}_{4}$ as mobile phase at a flow rate of $0.2 \mathrm{~mL} / \mathrm{min}$. Concentrations were determined by using a standard curve.

\section{Statistical Analysis}

The data collected by triplicate was used to calculate the mean value and the standard error

\section{Results and Discussion}

\section{Peanut Hulls as Support Material}

Peanut hull is a lignocellulosic material that due to its apparent composition could be potentially used as support matrix in beer fermentation (Fig. 1a). It presents a porous structure suitable for the adsorption of micro particles such as microorganisms. Due to this porous structure its mass is light and can be easy grinded. The use of this residual was also reported as adsorbent in the decontaminating of wastewaters containing heavy metals (Rozumová et al., 2016; Tasar et al., 2014; Opeolu et al., 2010) and organic pollutant such as dyes (Tanyildizi, 2011; Safarik and Safarikova, 2010). Regarding immobilization studies, there are several reports on the use of materials for yeast immobilization; which include polyvinyl alcohol, $\kappa$-carrageenan, sodium alginate and ceramic foam (Bezbradica et al., 2007; Decamps et al., 2004; Nedovic et al., 2001). However, these materials are relatively expensive compared to lignocellulosic residues. The support cost is extremely important and restrictive for the implementation of processes at the industrial scale.

Natural lignocellulosic materials such as peanut hulls must be conditioned before using them as supports for cell immobilization to increase or create micro regions allowing cells adhesion. As result of the conditioning process the size of the particles have reduced due to the delignification treatment (Fig. 1b). Excessive exposure time to this alkali $(\mathrm{NaOH} 0.5 \% \mathrm{w} / \mathrm{v})$ or the increase of its concentration can substantially reduce the size of the particles affecting unfavourably the adsorption capability (data do not showed). The conditioning process is mostly carried out by partial delignification using mineral acids or alkali at different concentrations (Branyik et al., 2004; Kopsahelis et al., 2007; Dragone et al., 2008). The specific treatment (acid or alkali) is chosen based on the modifications induced by the treatment; for instance, base-treated supports are more hydrophobic (negatively charged material) compared to the acid-base treated supports. The modification can enhance cell adhesion but makes the support more floatable (Branyik et al., 2004; Pires et al., 2012). Based on this information, the use of $\mathrm{NaOH}$ was chosen for the conditioning of peanut hulls.

The chemical composition of agroindustrial residues differs among them depending on the type of raw material used. The difference is based on the proportion of lignin to cellulose in the lignocellulose fraction. 


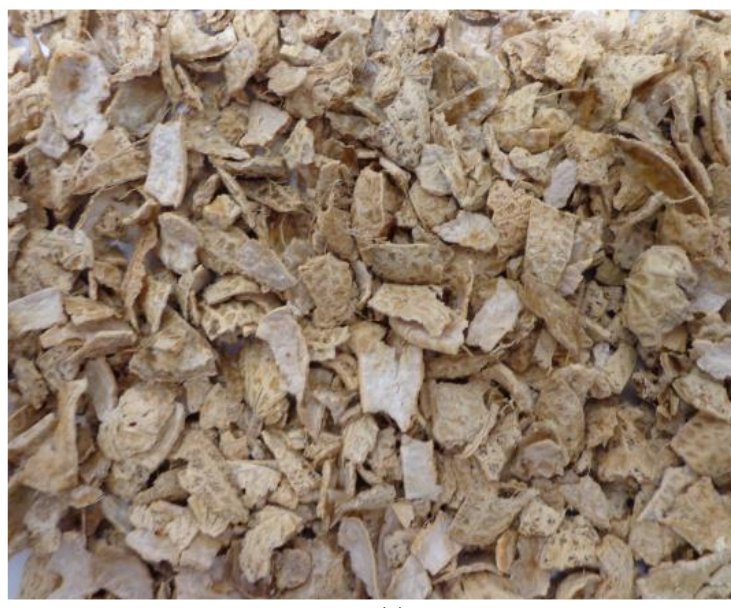

(a)

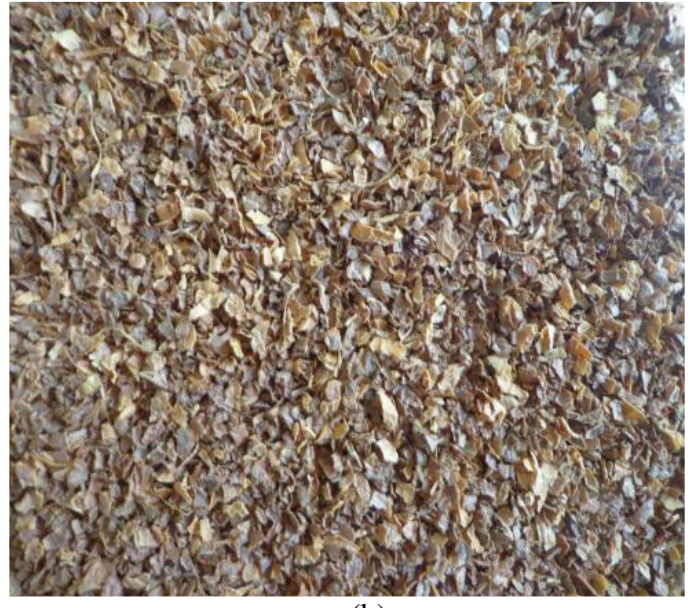

(b)

Fig. 1: Raw peanut hulls (a) and support material after delignification treatment (b)

The variation in the lignin to cellulose proportion determines the capability of cell adsorption on the support material. In this study, the delignification treatment was done by immersion of ground peanut hulls in $0.5 \%(\mathrm{v} / \mathrm{v}) \mathrm{NaOH}$.

\section{Fourier Transform Infrared Spectroscopy (FTIR)}

The pattern of cell adherence onto the treated peanut hulls could be attributable to the active groups and bonds generated on its surface. The elucidation of active sites was performed by FTIR spectrophotometry. Peaks identified in the FTIR spectrum of the supports (Fig. 2) were assigned to various groups and bonds in accordance with the respective wavenumbers $\left(\mathrm{cm}^{-1}\right)$. The presence of functional groups depends on the sample treatment. The absorption peak at $3344 \mathrm{~cm}^{-1}$ indicate the presence of free or hydrogen bonded $\mathrm{O}-\mathrm{H}$ groups, which can be associated to the presence of cellulose and lignin (Gnanasambandam and Proctor, 2000). The broad mixed stretching vibration adsorption band was reduced considerably following the $\mathrm{NaOH}$ treatment (Fig. 2b). The peak determined at $1732 \mathrm{~cm}^{-1}$ (Fig. 2a), which is not observed in the delignified sample, corresponds to the stretching vibration of the carboxylic group $(\mathrm{C}=\mathrm{O})$. The absence of the adsorption band in this point may be attributed to the conversion of carboxyl groups during the treatment of peanut hull. The peak at $1369 \mathrm{~cm}^{-1}$ was caused by the $\mathrm{O}-\mathrm{H}$ bending. The peak at $1265 \mathrm{~cm}^{-1}$ is indicative of the $\mathrm{O}-\mathrm{H}$ in-plane bending cellulose. Additionally, the $\mathrm{C}-\mathrm{O}$ band at $1026 \mathrm{~cm}^{-1}$ due to $-\mathrm{OCH}_{3}$ group confirms the presence of the lignin structure in the support (Farinella et al., 2007). These findings indicate that the $\mathrm{NaOH}$-treatment diminished the content of lignin. It is clear from the FTIR spectra that hydroxyl and $-\mathrm{OCH}_{3}$ groups are present at high levels. The adherence of yeast cells onto the support may be likely due to the electrostatic attractions between groups of opposite charges.

\section{Attachment of Yeast Cells on Support Materials}

In aqueous solution, cells normally attach to a solid material according to its affinities to the functional groups present on its surface. Peanut hulls are mainly composed of lignocellulose. In this study, peanut hulls were previously delignified using $0.5 \%(v / v) \mathrm{NaOH}$. This step was performed with the purpose of increasing the cell attachment. After partial delignification and conditioning, the support material was used for the immobilization of yeasts and fermentation experiments were performed with such biocatalyst. The binding capacity of cells onto the supports depends on many factors including: medium composition, $\mathrm{pH}$ and temperature, the physiological state of cells and the net charge of the material surface. The dynamic of cell attachment during the fermentation process is very complex since the cultivation conditions are continuously changing. For instance, through the fermentation process the $\mathrm{pH}$ diminishes due to the production of organic acids, the ethanol content increases due to sugar fermentation and several compounds are generated. Figure 3 shows the number of cells attached onto the support material before treatment and after delignification. It is clearly observed that delignification of peanut hulls with $0.5 \%(w / v) \mathrm{NaOH}$ had an enormous effect on cell attachment when compared to non-treated supports. In the case of the $\mathrm{NaOH}$-treated support, the maximal cell attachment $\left(2.56 \times 10^{8}\right.$ cells $/ g$ of dried support) was reached between the 16.5 and $20.5 \mathrm{~h}$ of cultivation. After this time point, the cell concentration remained almost constant.

Both the physical structure of the support material (pores and their distribution) and the physiological state of cells are important factors that may influence the attachment of cells onto the material (Gallardo-Moreno et al., 2004; Pereira et al., 2000). Thus, the growth phase may have a strong impact on the adsorption properties. 

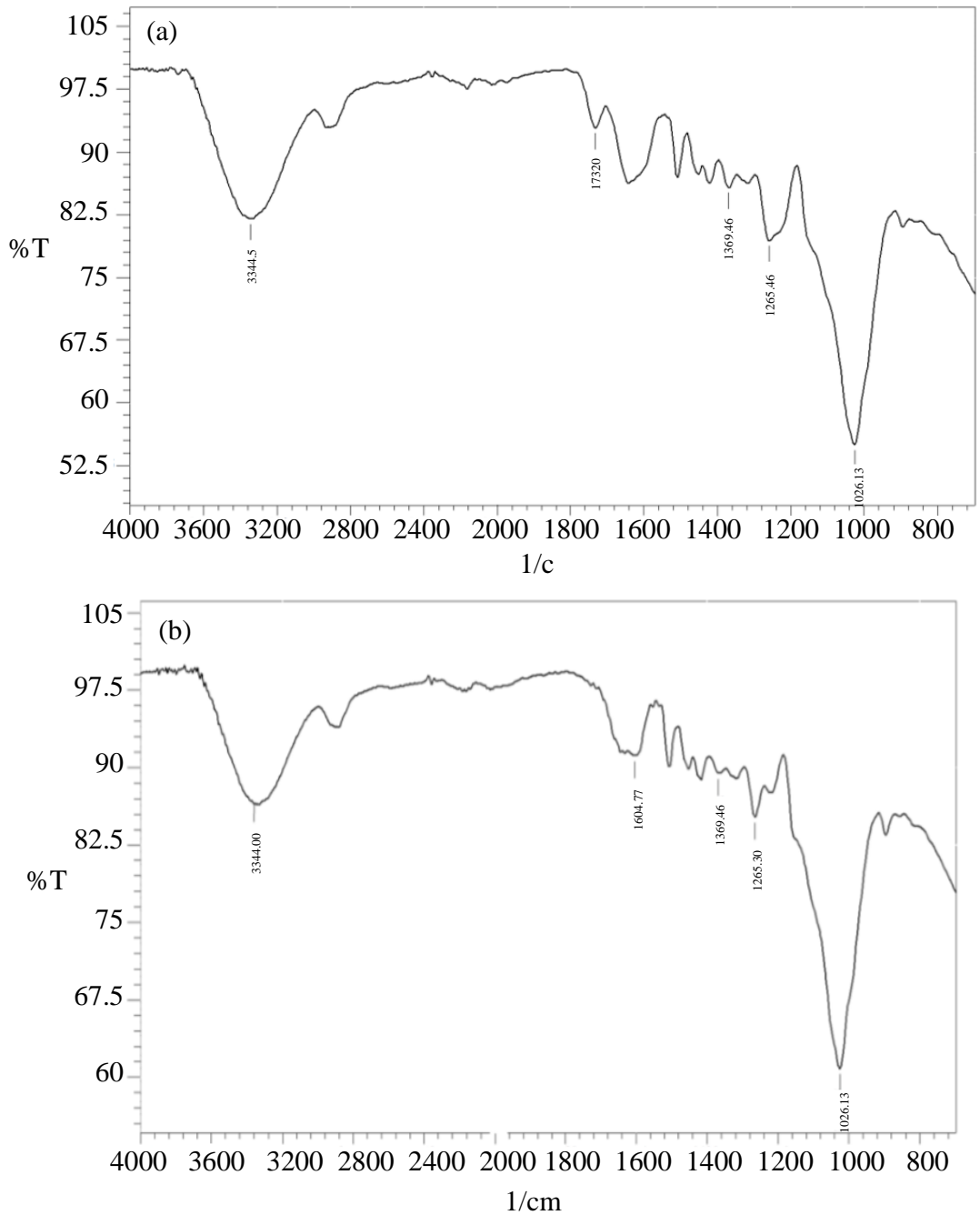

Fig. 2: FTIR spectrum of the support material made from peanut hulls before (a) and after delignification with $0.5 \% \mathrm{v} / \mathrm{v} \mathrm{NaOH}(\mathrm{b})$. Free or hydrogen bonded O-H group (peak at 3344), stretching vibration of C = O group (peak at $1732 \mathrm{~cm}-1$ ), O-H bending (peak at $1369 \mathrm{~cm}-1$ ) $\mathrm{O}-\mathrm{H}$ in-plane bending (peak at $1265 \mathrm{~cm}-1$ ), $-\mathrm{OCH} 3$ group (peak at $1026 \mathrm{~cm}-1$ )

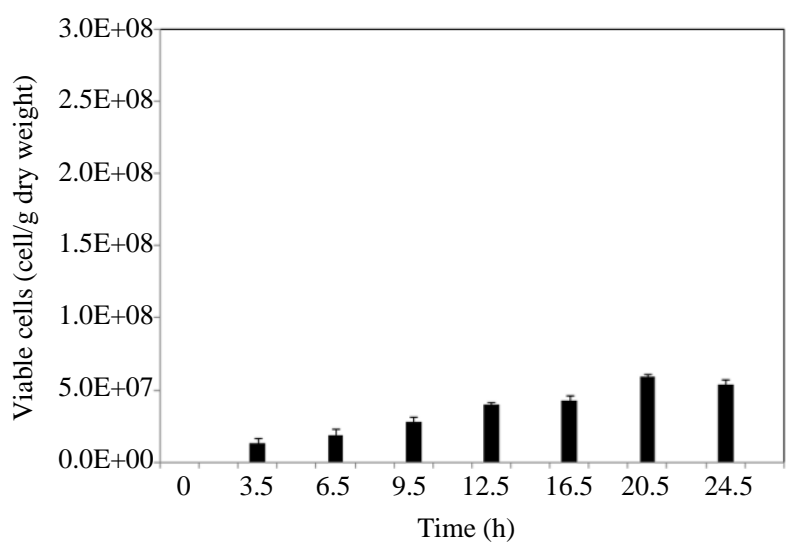

(a)

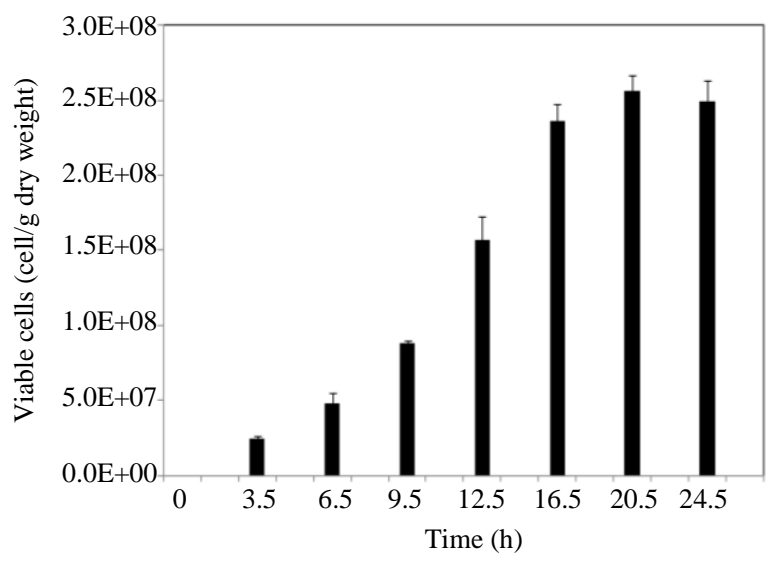

(b)

Fig. 3: Concentration of yeast cells attached to the support material: without delignification (a) and after delignification (b) when cultivated in $12{ }^{\circ}$ Brix laboratory malt wort at $25^{\circ} \mathrm{C}$ and $120 \mathrm{~min}^{-1}$ 

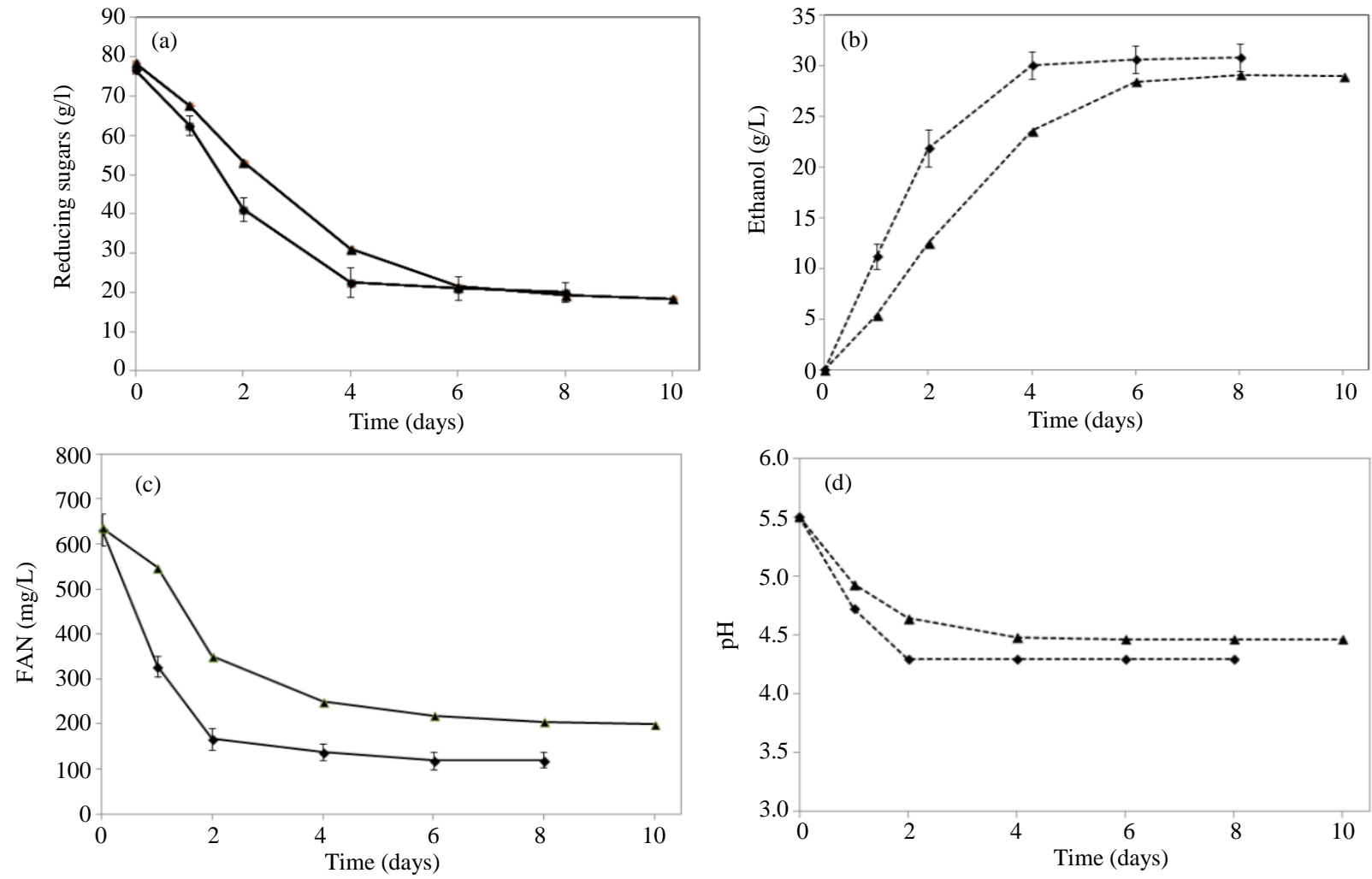

Fig. 4: Kinetics of fermentations carried out with free $(\boldsymbol{\Delta})$ and immobilized cells onto the support $(\bullet)$, at $15^{\circ} \mathrm{C}$ in $14^{\circ} \mathrm{Brix}$ laboratory malt wort. Reducing sugar consumption (a), ethanol production (b), free amino nitrogen consumption, FAN (c) and pH change during fermentation trials $(\mathrm{d})$

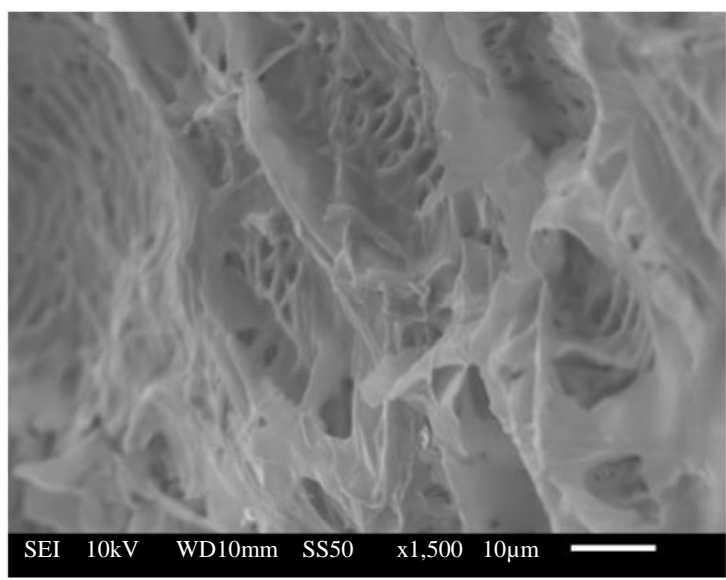

(a)

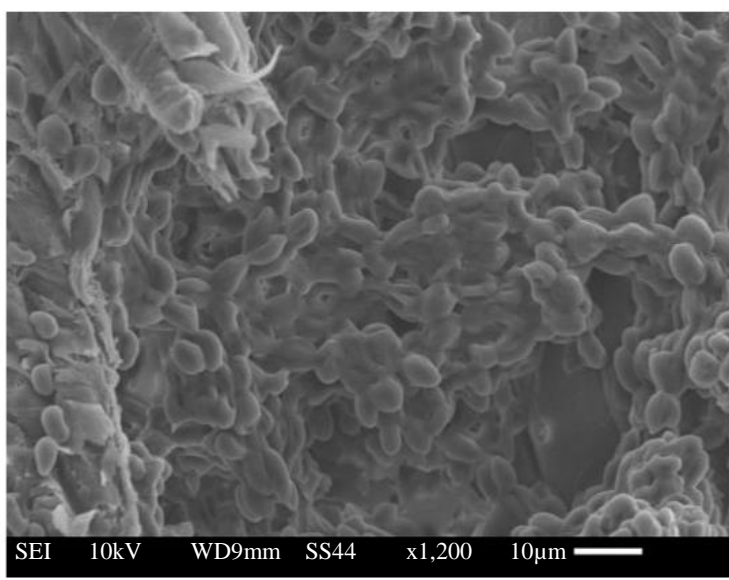

(b)

Fig. 5: SEM micrograph of the support before (a) and after three successive usages in experiments of beer fermentation (b)

It has been reported that the stationary phase favours the attachment of $S$. cerevisiae onto support materials (Kregiel et al., 2012). It is known that cells from the log phase are usually characterized by a greater sensitivity to changing environmental factors and lower resistance to stress. In our experiments, the immobilization of Saccharomyces cerevisiae S-23 onto the
$\mathrm{NaOH}$-treated support particles was characterized by a gradual attachment of cells reaching a maximum towards $20.5 \mathrm{~h}$ of cultivation.

\section{Fermentations with Immobilized Yeast Cells}

Beer fermentation is normally carried out with free suspended cells. This fermentation practice has some 
disadvantages, such as the loss of cell viability along successive fermentations, a diminished yeast fermentative capability at low fermentation temperatures and the need of continuous propagation and successive filtrations of the product to separate the cells. Due to these limitations, the use of immobilization techniques has been investigated in a model alcoholic fermentation, such as beer fermentation. Several studies showed that the immobilization of cells in polymeric matrixes, such as calcium alginate, improves their fermentative behaviour in terms of ethanol production and sugar consumption rate. Additionally, cell viability remains high and cells are easily recovered from the fermentation broth. Current investigations are focused on finding a practical use of natural supports in beer fermentation technology. Our study supports the use of peanut hulls as support material for immobilization of yeast and its application in beer fermentation. The fermentation kinetics obtained with immobilized and free suspended cells are showed in the Fig. 4.

The analysis performed on the first two days of fermentation revealed that reducing sugar consumption and ethanol production rates were higher when immobilized cells were used $(18.37 \pm 1.63 \mathrm{~g} /$ day and $10.95 \pm 0.91 \mathrm{~g} /$ day, respectively), compared to fermentations carried out with free suspended cells $(12.61 \pm 1.01 \mathrm{~g} /$ day and $6.28 \pm 0.48 \mathrm{~g} /$ day, respectively). Maximum ethanol productivity was attained with immobilized cells $(7.7 \pm 0.34 \mathrm{~g} /$ Lxday), showing the efficiency of the biocatalyst for alcoholic fermentation. In experiments carried out with immobilized cells, the fermentation time was 4 days, in comparison to fermentations with suspended cells that lasted more than 6 days (until gas production has stopped). Regarding to $\mathrm{pH}$ changes, a higher rate of $\mathrm{pH}$ decrease was observed during the first two days in fermentations performed with immobilised cells. With respect to FAN change, a higher FAN consumption rate was observed in fermentations implemented with immobilised cells. At the end of the experiments, the overall FAN consumption in fermentations conducted with immobilized cells was higher when compared to fermentations carried out with free suspended cells.

Interestingly, successive fermentation experiments performed with the same biocatalyst showed an attractive fermentative behaviour, suggesting that the repetitive use of the biocatalyst is viable.

SEM analysis of the support (after three successive usages) revealed important information on the surface morphology. It is observed that the immobilization mainly occurred in the cavities of the support structure (Fig. 5a). Adhesion of yeast cells to a support material depends on complex physicochemical interactions between the cell surface, the support and the liquid phase and on the charge of the yeast cell surface determined by the presence of functional groups. According to the literature, yeast cells are predominantly negatively charged due to the presence of carboxyl, phosphoryl and hydroxyl groups (White and Walker, 2011). The existence of localized positive charges on the yeast cell surface and increased cell-surface hydrophobicity also participate in the cell adhesion process (Hermansson, 1999; Liu et al., 2004). As seen in the Fig. 5b, the support material has cavities in its structure and then the cells can be found attached inside to the cavities. As mentioned earlier, yeast cells are adhered to the surface as a result of either natural entrapment into the porous cellulosic material or due to physical adsorption by electrostatic forces. An effective immobilization of yeast cells was established by the ability of the biocatalyst (after gently washing to remove the weak attached cells) to perform efficiently repeated batch fermentations (three continuous repetitions) using the same fermentation medium $\left(14^{\circ} \mathrm{C}\right.$ Brix laboratory malt wort) at $15^{\circ} \mathrm{C}$. Fermentation times were short, indicating that the biocatalyst does not require an adaptation time in the fermentation medium.

The main risk in fermentations carried out with yeasts immobilized onto natural supports is the occurrence of cell detachment due to the relatively weak interaction of the cell with the support in a changing environment in terms of ionic strength, $\mathrm{pH}$, medium composition, mechanical stress, etc. (Pilkington et al., 1998). During fermentation the formation of free biomass (data not showed) was observed and it could have contributed to substrate consumption. Nevertheless, the fact that immobilized cells can be easily recovered from the medium and be reused in subsequent fermentations generates an attractive advantage that should be validated through future evaluations comprising a repeated batch fermentation approach.

\section{Conclusion}

The results of FTIR data indicate that the treatment of the support material with $\mathrm{NaOH}(0.5 \%$ w/v $)$ had an important effect of the cell attachment properties. Following this process, the content of lignin is diminished, which improves the attachment of yeast cells onto the support. Under the tested conditions, the maximal cell adhesion $\left(2.56 \times 10^{8}\right.$ viable cells/g dried support) was reached after $20.5 \mathrm{~h}$ of cultivation. The concentration of cells adhered onto the support remained constant at further time points, suggesting that a pseudo-equilibrium between cell adhesion and detachment was established. The peanut hulls keep the physical integrity along successive fermentations as confirmed by SEM observation and a high adhesion capability of viable cells.

From the fermentation kinetic point of view, immobilization improved the fermentative behaviour of 
Saccharomyces cerevisiae S-23 in terms of ethanol production and reducing sugar consumption rates when compared to fermentations conducted with free suspended cells. Under the tested conditions, fermentation of $14^{\circ} \mathrm{C}$ Brix malt wort has ended in approximately four days in comparison to fermentation with free cells that lasted more than six days.

Based on the evidence generated herein, peanut hulls are proposed as an attractive biocatalyst for beer fermentation. From the sensory point of view, more studies are needed to evaluate the impact of the immobilization of yeasts in the production of compounds involved in the sensory quality of the product. In addition, future studies on pilot and large scale fermentations using peanut hulls as support material are needed in order to validate the results obtained under laboratory conditions.

\section{Acknowledgements}

This work was partially supported by the National University of San Marcos (RR N 00837-R-16).

\section{Author's Contributions}

Waldir D. Estela-Escalante: Worked on preparation and treatment of the support material, fermentation experiments, analysis and interpretation of data as well as writing of the document

Sergio Rosales-Mendoza: Designed the study strategy, advised on the scanning electron microscopy as well as reviewing and writing of the manuscript

Mario Moscosa-Santillán: Advised the team on FTIR analysis and in the manuscript reviewing

\section{Ethics}

There are not any ethical issues to declare that could arise after the publication of this manuscript.

\section{Conflict of Interest}

The authors declare that they have no competing interests. The corresponding author affirms that all of the authors have read and approved the manuscript.

\section{References}

Almonacid, S.F., A.L. Nájera, M.E. Young, R.J. Simpson and C.A. Acevedo, 2012. A comparative study of stout beer batch fermentation using free and microencapsulated yeasts. Food Bioprocess Technol., 5: 750-758. DOI: 10.1007/s11947-009-0299-3

ASBC, 1992. Methods of Analysis. 8th Edition. Minnesota, American Society of Brewing Chemists, USA.
Bardi, E., A.A. Koutinas and M. Kanellaki, 1997. Room and low temperature brewing with yeast immobilized on gluten pellets. Process. Biochem., 32: 691-696. DOI: 10.1016/S0032-9592(97)00030-7

Bekatorou, A., A. Sarellas, N.G. Ternan, A. Mallouchos, M. Komaitis, et al., 2002. Low-temperature brewing using yeast immobilized on dried figs. J. Agric. Food Chem., 50: 7249-7257. DOI: 10.1021/jf020291q

Bezbradica, D., B. Obradovic, I. Leskosek-Cukalovic, B. Bugarski and V. Nedovic, 2007. Immobilization of yeast cells in PVA particles for beer fermentation. Process. Biochem., 42: 1348-1351.

DOI: $10.1016 /$ j.procbio.2007.04.009

Branyik, T., A.A. Vicente, R. Oliveira and J.A. Teixeira, 2004. Physicochemical surface properties of brewing yeast influencing their immobilization onto spent grains in a continuous reactor. Biotechnol. Bioeng., 88: 84-93. DOI: 10.1002/bit.20217

Branyik, T., D.P. Silva, A.A. Vicente, R. Lehnert and J.B. Almeida e Silva et al., 2006. Continuous immobilized yeast reactor system for complete beer fermentation using spent grains and corncobs as carrier materials. J. Industrial Microbiol. Biotechnol., 33: 1010-1018. DOI: 10.1007/s10295-006-0151-y

Brown, P., I.A. Jefcoat, D. Parrish, S. Gill and E. Graham, 2000. Evaluation of the adsorptive capacity of peanut hull pellets for heavy metals in solution. Adv. Environ. Res., 4: 19-29. DOI: 10.1016/S1093-0191(00)00004-6

Decamps, C., S. Norton, E. Nationale, N. Cedex and R.J. Neufeld, 2004. Continuous pilot plant scale immobilization of yeast in $\kappa$-carrageenan gel beads. AIChE J., 50: 1599-1605. DOI: 10.1002/aic.10143

Dragone, G., S.I. Mussatto and J.B. Almeida e Silva, 2007. High gravity brewing by continuous process using immobilised yeast: Effect of wort original gravity on fermentation performance. J. Int. Brew., 113: 391-398. DOI: 10.1002/j.2050-0416.2007.tb00766.x

Dragone, G., S.I. Mussatto and J.B. Almeida e Silva, 2008. Influence of temperature on continuous high gravity brewing with yeasts immobilized on spent grains. Eur. Food Res. Technol., 228: 257-264. DOI: $10.1007 / \mathrm{s} 00217-008-0930-y$

Farinella, N.V., G.D. Matos and M.A.Z. Arruda, 2007. Grape bagasse as a potential biosorbent of metals in effluent treatment. Bioresour. Technol., 98: 1940-1946. DOI: 10.1016/j.biortech.2006.07.043

Gallardo-Moreno, A.M., M.L. Gonzalez-Martin, C. PerezGiraldo, J.M. Bruque and A.C. Gomez-Garcia, 2004. The measurement temperature: an important factor relating physicochemical and adhesive properties of yeast cells to biomaterials. J. Colloid Interface Sci., 271: 351-358. DOI: 10.1016/j.jcis.2003.12.008 
Gnanasambandam, R. and A. Proctor, 2000. Determination of pectin degree of esterification by diffuse reflectance Fourier transform infrared spectroscopy. Food Chem., 68: 327-332. DOI: 10.1016/S0308-8146(99)00191-0

Hermansson, M., 1999. The DLVO theory in microbial adhesion. Colloids Surf. B. Biointerfaces, 14: 105-119. DOI: 10.1016/S0927-7765(99)00029-6

Kopsahelis, N., M. Kanellaki and A. Bekatorou, 2007. Low temperature brewing using cells immobilized on brewer's spent grains. Food Chem., 104: 480-488. DOI: 10.1016/j.foodchem.2006.11.058

Kourkoutas, Y., A. Bekatorou, I. Banat, R. Marchant and A. Koutinas, 2004. Immobilization technologies and support materials suitable in alcohol beverages production. review. Food Microbiol., 21: 377-397. DOI: $10.1016 /$ j.fm.2003.10.005

Kregiel, D., J. Berlowska and W. Ambroziak, 2012. Adhesion of yeast cells to different porous supports, stability of cell-carrier systems and formation of volatile by-products. World J. Microbiol. Biotechnol., 28: 3399-3408. DOI: 10.1007/s11274-012-1151-X

Lie, S., 1973. The EBC-ninhydrin method for determination of free alpha amino nitrogen. J. Int. Brew., 79: 37-41. DOI: 10.1002/j.2050-0416.1973.tb03495.x

Liu, Y., S.F. Yang, Y. Li, H. Xu and L. Qin et al., 2004. The influence of cell and substratum surface hydrophobicities on microbial attachment. J. Biotechnol., 110: 251-256.

DOI: 10.1016/j.jbiotec.2004.02.012

Miller, G.L., 1959. Use of dinitrosalicylic acid reagent for determination of reducing sugar. Anal Chem., 31: 426-428. DOI: org/10.1021/ac60147a030

Nedovic, V.A., B. Obradovic and I. Leskos, 2001. Electrostatic generation of alginate microbeads loaded with brewing yeast. Process Biochem., 37: 17-22. DOI: 1016/S0032-9592(01)00172-8

Opeolu, B.O., O. Bamgbose, T.A. Arowolo and M.T. Adetunji, 2010. Utilization of biomaterials as adsorbents for heavy metals' removal from aqueous matrices, Sci. Res. Essays, 5: 1780-1787.

DOI: 10.1016

Pereira, M.A., M.M. Alves, J. Azeredo, M. Mota and R. Oliveira, 2000. Influence of physico-chemical properties of porous microcarriers on the adhesion of an anaerobic consortium. J. Industrial Microbiol. Biotechnol., 24: 181-186.

DOI: $10.1038 /$ sj.jim.2900799
Pilkington, P.H., A. Margaritis, N.A. Mensour and I. Russel, 1998. Fundamentals of immobilized yeast cells for continuous beer fermentation. review. J. Inst. Brew., 104: 19-31. DOI: 10.1002/j.2050-0416. 1998.tb00970.x

Pires, E.J., A. Ruiz, J.A. Teixeira and A.A. Vicente, 2012. A new approach on brewer's spent grains treatment and potential use as lignocellulosic yeast cells carriers. J. Agric. Food Chem., 60: 5994-5999. DOI: $\quad 10.1021 / \mathrm{jf} 300299 \mathrm{~m}$

Raymond, M.C., R.J. Neufeld and D. Poncelet, 2004. Encapsulation of brewer yeast in chitosan coated carrageenan microspheres by emulsification/thermal gelation. Artif. Cells Blood Substit. Biotechnol., 32: 275-291.

Rozumová, L., O. Zivotský, J. Seidlerová, O. Motyka and I. Safarík et al., 2016. Magnetically modified peanut husks as an effective sorbent of heavy metals. J. Environ. Chem. Eng., 4: 549-555.

DOI: $10.1016 /$ j.jece.2015.10.039

Safarik, I. and M. Safarikova, 2010. Magnetic fluid modified peanut husks as an adsorbent for organic dyes removal. Physics Procedia, 9: 274-278.

DOI: $10.1016 /$ j.phpro.2010.11.061

STATISTA, 2017. Production of peanut. Stat. Portal.

Tanyildizi, M.S., 2011. Modeling of adsorption isotherms and kinetics of reactive dye from aqueous solution by peanut hull. Chem. Eng. J., 168: 12341240. DOI: 10.1016/j.cej.2011.02.021

Tasar, S., F. Kaya and A. Ozer, 2014. Biosorption of lead(II) ions from aqueous solution by peanut shells: Equilibrium, thermodynamic and kinetic studies. J. Environ. Chem. Eng., 2: 1018-1026. DOI: $10.1016 /$ j.jece.2014.03.015

Virkajarvi, I. and N. Pohjala, 2000. Primary fermentation with immobilized yeast: Some effects of carrier materials on the flavour of the beer. J. Int. Brew., 106: 311-318.

DOI: 10.1002/j.2050-0416. 2000.tb00071.x

White, J.S. and G.M. Walker, 2011. Influence of cell surface characteristics on adhesion of Saccharomyces cerevisiae to the biomaterial hydroxylapatite. Ant. van Leeuwenhoek, 99: 201-209. DOI: $10.1007 / \mathrm{s} 10482-010-9477-6$

Willaert, R. and V.A. Nedovic, 2006. Primary beer fermentation by immobilised yeast: A review on flavour formation and control strategies. J. Chem. Technol. Biotechnol., 81: 1353-1367.

DOI: $10.1002 /$ jctb. 1582 